as a source of $C o \mathrm{Q}$ in view of the recent attempts to produce Co $\mathrm{Q}$ by bacterial fermentation of certain synthetic media ${ }^{8}$. The detailed paper on these and related aspects will be published elsewhere

We wish to thank Dr. T. Ramasarma and Dt. S.C. Pillat for their interest and advice.

Department of Biochemistry, Indian Institute of Science, Bangalore 12, India

C. V. Viswanathan, J. Jayaraman, (Miss) B. Meera BaI and P.V.R. SUbRAHMANYAM

Eingegangen am 31. Oktober 1960

1) Green, D.E., and R. L. Lester: Fed. Proc. 18, 987 (1959). 2) Morton, R.A.: Nature [London] 182, $1764(1958) .-3$ ) LESTER,
R.L., and F.L. Crane: J. Biol. Chem. 234 (8), 2169 (1959). 4) Koniuszy, F.R., P.M. Gale, A.C. PAGE Jr. and K. Folkers; Arch. Biochem. Biophys. 87, 298 (1960). - 5) Olson, R.E., and G.H. Dialameh: Biochem. Biophys. Res. Comm. 2 (2), 198 (1960).6) Viswanathan, C.V., and S.C. PILlaI: Indian Inst. of Sci. Golden Jubilee Res. Volume, 119 (1959). - i) Viswanathan, C.V., and S.C. PILLAI: Naturwissenschaften 46, 324 (1959). - ${ }^{8}$ ) PAGE Jr. A.C., P.M. Gale, M. Wallich, R.B. Walton, L. E. MCDAnIEL, M. B. WoodrufF and K. Folkers: Arch. Biochem. Biophys. 89, $318(1960)$.

\section{Coenzyme $Q$ (Ubiquinone) in Avian Egg and Embryo}

Consistent with the view of WARBURG $^{\mathbf{1}}$ ) that an embryo is an aerobic organism several oxidative enzymes $\left.\left.\left.{ }^{2}\right),{ }^{3}\right),{ }^{4}\right)$ and respiratory pigments ${ }^{5}$ ) have been shown to be present and to increase in quantity during development in chick embryo. Further, particulate material isolated from chick embryonic liver homogenates has been shown to contain coenzyme $Q$ (Co $Q$ ) and evidence has been deduced for its participation in electron transport activities similar to its role in animal tissue mitochondria ${ }^{5}$ ). The chick embryo inside the shell, being a "closed unit" and free from microbial contamination, should have all its supply of Co $Q$ deposited in the egg by the hen or should synthesize it during development, if absent in the egg. The data presented here show that $\mathrm{CO}_{\mathrm{O}} \mathrm{Q}$ is present in eggs and it is progressively incorporated into the embryo during development.

In eggs, $C o Q$ was found entirely in yolks and the amounts present in three batches are given in the Table. The mean values

Table. Coenzyme $Q$ content of Hens' Eggs and Chick Embryos. Wet weight (in gm.) and Co Q (umole)

\begin{tabular}{|c|c|c|c|c|c|c|}
\hline \multicolumn{7}{|c|}{ Yolks from fresh eggs *) } \\
\hline $\begin{aligned} \text { Batch 1: } & \text { wet weight } \\
& \text { Co } Q .\end{aligned}$ & $\begin{array}{l}18 \cdot 0 \\
0.131\end{array}$ & $\begin{array}{l}16 \cdot 5 \\
0 \cdot 162\end{array}$ & $\left|\begin{array}{l}17 \cdot 0 \\
0 \cdot 120\end{array}\right|$ & $\left|\begin{array}{l}18 \cdot 5 \\
0 \cdot 180\end{array}\right|$ & $\left|\begin{array}{l}17 \cdot 5 \\
0 \cdot 172\end{array}\right|$ & $\mid \begin{array}{l}18 \cdot 0 \\
0 \cdot 166\end{array}$ \\
\hline $\begin{aligned} \text { Batch 2: wet weight } & \text { Co } Q .\end{aligned}$ & $\begin{array}{l}14 \cdot 0 \\
0 \cdot 138\end{array}$ & $\begin{array}{l}15 \cdot 0 \\
0 \cdot 143\end{array}$ & $\begin{array}{l}16 \cdot 0 \\
0.119\end{array}$ & $\begin{array}{l}15 \cdot 5 \\
0 \cdot 163\end{array}$ & $\begin{array}{l}20 \cdot 0 \\
0 \cdot 133\end{array}$ & \\
\hline $\begin{array}{c}\text { Batch 3: wet weight } \\
\text { Co } \mathrm{O} . \\
\end{array}$ & $\begin{array}{l}17 \cdot 0 \\
0.088 \\
\end{array}$ & $\begin{array}{l}16 \cdot 5 \\
0.087 \\
\end{array}$ & $\begin{array}{l}16 \cdot 0 \\
0 \cdot 088 \\
\end{array}$ & $\begin{array}{l}16 \cdot 0 \\
0 \cdot 104 \\
\end{array}$ & & \\
\hline $\begin{array}{l}\text { mbryos } \\
\text { wet weight. } \\
\text { Co } Q\end{array}$ & $\mid \begin{array}{l}0-7 \text { th } \\
0.06 \\
0.064\end{array}$ & $\begin{array}{c}13-14 \text { th } \\
10.00 \\
0.124\end{array}$ & $\begin{array}{l}15 \text { th } \\
12 \cdot 50 \\
0 \cdot 139\end{array}$ & \begin{tabular}{|l|}
16 th \\
$16 \cdot 00$ \\
$0 \cdot 164$
\end{tabular} & $\begin{array}{l}17-18 \\
21 \cdot 00 \\
0 \cdot 152\end{array}$ & \\
\hline
\end{tabular}

*) Because of the high lipid content of yolks, a high concentration of alkali $(0.5 \mathrm{gm}$. NaOH per gm. wet weight) was used and the saponification time was reduced to $20 \mathrm{~min}$. to minimize destruction of Co $Q$.

of $\mathrm{Co} Q$ content in the three batches are $0.155( \pm 0.024)$, $0.147( \pm 0.038)$ and $0.092( \pm 0.008)$ umole per egg yolk. The variation in batch 3 suggests that Co $Q$ content of eggs might depend on the hen's feed as in the case of vitamins A and $E^{6}$ ). Progressively increasing amounts of $\mathrm{Co}_{\mathrm{O}} \mathrm{Q}$ were found in the developing embryo and by about the 15 th day of development negligible amounts of $\mathrm{Co} Q$ were left in the residual material in the egg.

The procedure used in the isolation of Co $Q$ from eggs and embryos of White Leghorn variety hens consisted of saponification in presence of pyrogallol, extraction of the unsaponifiable matter with hexane, removal of carotenoids by washing hexane layer with $80 \%$ ethanol, freezing out most of sterols from petroleum ether $\left(40\right.$ to $\left.60^{\circ}\right)$ at $0^{\circ}$, and fractionation on silicic acid column. The $50 \% \mathrm{CHCl}_{3}$ in petroleum ether fraction showed small but definite peaks at $275 \mathrm{~m} \mu$ and on reduction with $\mathrm{NaBH}_{4}$ maximum decrease in absorption was found at $275 \mathrm{mu}$, indicating the presence of $\mathrm{Co} Q$, from which the amount of $\mathrm{Co} Q$ was calculated $\left.{ }^{7}\right)$. The reduced spectra, however, showed absorption peaks at $280 \mathrm{~m} \mu$ for egg fractions and 272 and $280 \mathrm{~m} \mu$ for embryo fractions. In all cases the presence of Co $Q$ was confirmed by reverse phase paper chromatography ${ }^{8}$ ) and $Q_{10}$ was the only form found. However, egg yolk unsaponifiable matter contained another compound having $R_{f} 0.90$ in $80 \%$ n-propanol system, giving positive test with leucomethylene blue spray and showing an absorption peak at $265 \mathrm{~m} \mu$ which was not reduced with $\mathrm{NaBH}_{4}$. [The leucomethylene blue spray developed by FolKeR's group ${ }^{4}$ ) for detection of quinones was, however, found to be not specific for quinones since some ring ketones, particularly unsaturated ones, also gave a positive test]. Further, infrared data (peak at $5.82 \mu$ ) suggested that this compound possibly is a saturated ring ketone or a $\alpha$-diketone, but not a quinone.

The unsaponifiable matter of egg yolk and chick embryo also contained reducing compounds $\left(\alpha, \alpha^{\prime}\right.$-dipyridyl-FeCl positive) having $R_{f} 0.90$ in $80 \% \mathrm{n}$-propanol system which are different from ubichromenol $\left(R_{f}, 0.42\right)$ and $\alpha$-tocopherol $\left(R_{f}, 0.85\right)$ but appear to be similar to the compound described by MAHLER $^{5}$ ). A preparation of this compound from egg yolk showed absorption peaks at 272 and $310 \mathrm{m \mu}$.

Further work following the changes in Co $Q$, vitamin $\mathrm{E}$ and this new non-vitamin $\mathrm{E}$ reducing compound during embryonic development is in progress.

We are grateful to Drs. D.K. BANERJEE and B.H. IYER of the Organic Chemistry Department for the infrared analysis.

Department of Biochemistry, Indian Institute of Science, Bangalove 12, India

T. RAmasarma*), J. Jayaraman and P.S. Sarma

Eingegangen am 15. November 1960

*) C. S. I. R. Scientists' Pool Officer.

1) Warburg, O.: Biochem. Biophys. Acta 25, 429 (1957). 2) Albaum, H, G., A.B. Novikoff and M. OGur: J. Biol. Chem. 165, 125 (1946). ${ }^{3}$ ) SCElvola, M. E., and A. D. DE Barbiert: Bull. Soc. Chim. biol. 39, 1305 (1957). -4) BRAND, L., and H. R. MAHLER: J. Biol. Chem. 234, 1615 (1959). - 5) BRAND, L., C. DAHL and II. R. MAHLER: J. Biol. Chem. 235, 2456 (1960). - 6) DeuL jr. H. J.: The Lipids, vol. II, pp. 327, 503. London: Interscience Publishers 1955. - 7) Linn, B.O., A.C. PAGE jr., E.L. WONG, P.R. GALE, C.H. Shunk and K. Folkers: J. Amer. Chem. Soc. 81, 4007 (1959).5) Lester, R. L., and T. Ramasarma: J. Biol. Chem. 234, 672 (1959).

\section{The Localization of Copper in Agar Gel}

\section{Electrophoretic Patterns of Crustacean Blood}

Recently WHITTACKER ${ }^{1}$ ) was able to demonstrate that the two protein bands, obtained by starch gel electrophoresis after SMITHIEs ${ }^{2}$ ) from blood of two Orconectes species, both contain copper. Therefore he sectioned the gels horizontally and while one half was stained for protein with amidoblack $10 \mathrm{~B}$ dye, the other half was placed for 24 hours in a solution of $50 \mathrm{ml}$ of $10 \%$ aqueous sodium acetate and $3 \mathrm{ml}$ of alcoholic $0.1 \%$ rubeanic acid. In these circumstances the two protein bands of Orconectes blood stained a light greenish-black.

With this method however, we were unable to demonstrate copper in electropherograms of crustacean blood obtained by micro agar gel electrophoresis after WIEME $^{3}$ ). Moreover the time required in the method of WHITTACKER is too long because diffusion phenomena are very important in agar gels and bring about a broadening of the protein bands, preventing a sharp separation. Therefore the protein mixture is applied as a narrow band ( $4 \mathrm{~mm}$ long and $1 / 4 \mathrm{~mm}$ wide) and electrophoresis is completed in a very short time, the protein fractions being fixed immediately afterwards.

In order to overcome all these difficulties we established a more sensitive method for copper localization by complexation with rubeanic acid. The best results were obtained by incubating the gels, after electrophoresis, in a mixture of: glacial acetic acid $5 \mathrm{ml}$; alcohol $94 \% 70 \mathrm{ml}$; alcoholic $0.2 \%$ rubeanic acid $25 \mathrm{ml}$.

In these circumstances the proteins are fixed by the acetic acid-alcohol mixture and the $\mathrm{Cu}^{2+}$-ions set free in this medium are immediately precipitated in situ by the rubeanic acid. A greenish colour develops within 20 minutes and after 1 hour the positive fraction turns dark green. Copper estimation showed that the minimum amount of copper, demonstrable with our method is $0.132 \mu \mathrm{g} \mathrm{Cu}^{2+}$, put into the narrow slit on the application line.

In our experiments electrophoresis was carried out in 0.9 per cent special agar-Noble(Difco)gels of $\mathrm{p}_{\mathrm{H}}=8.4$. The tension between the electrodes is kept at 130 volts, the current 